\title{
Research on the Application of WeChat Official Platform in the Second Classroom of College English Teaching*
}

\author{
Biwen Yin \\ School of Foreign Language and Literature \\ Wuhan Donghu University \\ Wuhan, China
}

\begin{abstract}
In modern society, as the rapid development of network technique, new media such as WeChat and Microblog have become an important way for people to obtain information and communicate with each other. Making full use of these new media in college English teaching can get rid of the limitations of time and space, enrich the form and content of college English teaching and stimulate learners' learning initiative. This paper studies the application of WeChat Official Platform in the second classroom of College English teaching and proves that it is an effective complement to the college English teaching.
\end{abstract}

Keywords-WeChat Official Platform; the second classroom; college English teaching

\section{INTRODUCTION}

With the rapid development of computer technology, network technology and mobile device, surfing the internet with cell phone becomes more and more popular. According to the China Internet development report 2018, which was officially released by the China Internet association, the number of Chinese netizens has reached 802 million, with the penetration rate of $57.7 \%$. The number of mobile Internet users has reached 788 million, with 98.3 percent of them accessing the internet through mobile phones. WeChat is a mobile text and voice messaging communication service developed by Tencent in China. It is one the most popular social apps in the world. WeChat has multiple features including video chat, voice calling, SMS, games and $\mathrm{QR}$ code scanning. With so many functions, WeChat has begun to change people's lives, pioneering an unprecedented form of communication [1]. Among all WeChat users, college students occupy a large portion. The wide application of WeChat and its multiple functions can bring the college English teaching a new model.

*This article is one of the research results of Wuhan Donghu University teaching research project "Research on the Application of WeChat Official Platform in the Second Classroom of College English Teaching" (No.:180048).

\section{SeCOND Classroom of College ENGLish TeACHING AND WECHAT OFFICIAL PLATFORM}

\section{A. Second Classroom of College English Teaching}

In China, according to the College English Syllabus and College English Curriculum Requirements, the goal of college English teaching is to cultivate college students' practical English ability and improve their comprehensive quality and cultural accomplishment to meet the needs of social development, progress and international communication. At present, in most colleges in China, there are only four terms (altogether 2 years) for college students to learn English and there are only 48 classes in each term. College students take English classes 2 times a week, and each time lasts 90 minutes. It is difficult to achieve the goal of college English teaching within the limited class hours. Exploring and innovating the second classroom of college English can be a good way to solve this problem and meet the goal. The second classroom of college English can supplement the first classroom. Those activities which cannot be taken in the first classroom can be done in the second classroom. But traditional second classroom are limited by time, space and teaching methods, which cannot fully promote the enthusiasm and initiatives of students' learning. It is very necessary to innovate the teaching ideas of the second classroom of college English.

\section{B. WeChat Official Platform}

In the information age, college English teaching is constantly presented with opportunities and challenges. WeChat has continuously permeated into the learning field, bringing unprecedented influence to college English teaching [2]. As fairly popular mobile social software, WeChat integrates sending and sharing pictures, audio, video and text messages. Its openness, share, collaboration and interaction are the necessary conditions for foreign language learning. As WeChat has risen to dominate the Chinese social media space, WeChat Officlal Account is drawing a lot of interest these days. WeChat Official Account is the WeChat equivalent of a Facebook page. It is easy to apply for a WeChat Official Account. By adding WeChat Official Account ID, WeChat users will be able to see texts, images, audio and video posted by the WeChat Official Account. WeChat Official Account is 
characterized by convenience and immediacy. In this platform, information, texts, images, audio and video can be quickly gathered and transmitted to the WeChat followers. Apply WeChat Official Platform to the second classroom teaching can help learners to get rid of the limitations of space and time and its various functions can be used to assist college English teaching.

\section{Analysis of Advantages of Application of WeChat Official Platform in the Second Classroom of College English Teaching}

1) Convenience: There are no barriers to be a member of a WeChat Official Account. Any student who has a mobile phone can add the WeChat Official Account ID and becaome a member of a WeChat Official Platform. Once being a member, he can easily get all the information, including images, audio and video that are posted on the platform.

2) Immediacy: All WeChat Official Platforms have strong immediacy. When teachers share something important on the official platform, all WeChat followers who follow the official account can see it immediately.

3) Richness: WeChat has various functions, which integrates audio, video, images, texts and data. By using these functions, teachers can change traditional teaching method and enrich the teaching content. Boring textbooks can be changed into vivid video or pictures, and thus stimulate students' interest in learning. Finally, the improvement of English learning efficiency is realized.

4) Interactivity: There isn't enough time for students to discuss questions in the classroom and Chinese students are always shy to have a face to face communication with teachers. But on the WeChat Official Platform, students will feel free to express their own thoughts and raise their questions, so the teacher can better interact with students. Therefore, $a$ harmonious teacher-student relation can be established.

5) Flexibility: Most students only read textbooks in the process of learning, and they take little notice about the extracurricular books. College English teaching is to widen the horizons of students, not just in language, but also in their overall development and world knowledge[3]. For example, teachers can put the extracurricular passages on the WeChat Official Platform for students to read, and students can read them anytime and anywhere, and thus their reading range is expanded and flexibility in learning is increased.

\section{DESIGN IDEAS ON THE APPLICATION OF WECHAT} OfFicial Platform in the SeCOND Classroom of College ENGLISH TEACHING

\section{A. Taking Full Advantage of WeChat's Multiple Functions}

WeChat's multiple functions provide a good supplement for College English teaching. In the second classroom, teachers can find different kinds of audio and video materials and share them with the students on the WeChat Official Platform. Latest lectures and news video can arouse students' interest and improve their listening ability. The articles posted on the platform can be multifaceted. For example, teachers can post the study plan of this week on the platform, so that students can preview what they are going to learn. When a unit is finished, teachers can post some articles that are related to this unit for students to read, so that students' reading ability can be improved and their scope of knowledge is widened. WeChat has a strong communication function. Once students have questions about what they have learned, they can leave messages on the WeChat Official Platform. When the teacher sees them, he can answer their questions. The teacher even can record his answers and post it on the platform.

\section{B. Developing Emotional Teaching Model}

At present, College education pays more and more attention to the emotional communication between teachers and students. The application of WeChat Official Platform provides a bridge between teachers and students to communicate well and thus establishing a harmonious student-teacher relationship. By using WeChat, English teachers should pay attention to the changes of students' emotion in time and put forward reasonable suggestions for them. Students will get satisfaction and confidence from teachers' guidance and encouragement, which is good for their English learning.

\section{Involving Students in the Establishment of WeChat Official Platform}

In modern education, teacher's role has changed; they are no longer the only master of classroom. Teacher's role is to guide students to learn and teach them how to learn [4]. Students are the real master of learning. Let students involve in the establishment of WeChat Official Platform can arouse students' interest in learning. Teacher can give some suggestions, and then let students themselves to find related passages, video or audio to post on the platform. With the help of teacher, students can hold activities, such as topic discussion on the platform. Besides, teachers should collect students' feedback about the WeChat Official Platform on a regular basis to perfect it.

\section{PRACTICAL OPERATION OF WECHAT OFFICIAL PLATFORM IN THE SECOND CLASSROOM OF COLLEGE ENGLISH TEACHING}

\section{A. Creating a Wechat Official Account}

First, go to the website https:// mp.weixin.qq.com/and click on register and then follow the instruction, a WeChat Official Account can be created. Ask students to add the WeChat Official Account ID.

\section{B. Project Design}

The plan design includes two parts: previewing stage, and post-class stage. All these activities are taken in the second classroom.

1) Previewing stage: In this stage, teachers post the lesson plan on the platform, including learning goal, difficult point, language points and discussion topic. Students are required to read them to preview what they are going to learn. The forms of lesson plan can be diversified, such as video, audio and 
pictures. Teacher can also assign students to form different groups to collect background information and post them on the platform. This stage can help students get into the learning mode before the class begins.

2) Post-class stage: This stage is the extension of the first classroom and it will enhance and consolidate what students have learned in the first class. By means of WeChat Official Platform, teachers post related information, including articles, video and audio, on the platform to supplement textbooks. Teachers can also post the answers to the homework on the platform. If students have any problems about their homework or study, they can leave their questions on the message zone of the platform, and anyone who knows the answer can exlpain it to them.

\section{Feedback and Evaluation of Teaching Effect}

In traditional teaching, feedback and evaluation of teaching effect is done at the end of each term. By means of new technology, feedback and evaluation can be done at the end of each unit. Teachers can make a survey about students learning situation on the WeChat Official Platform. According to students' feedback, teachers can know how the effect of their teaching. If the effect is not good, teachers will find what the problems are and make an improvement.

\section{Notes About the Application of WeChat Official Platform in the Second Classroom of College English Teaching}

1) Normativity: The application of WeChat Official Platform in the second classroom of college English teaching should be normative. It means that students must obey teacher's orders to add the WeChat Official Account ID and become followers of it. When teachers post tasks on the platform, students must finish these tasks. Teachers are the administrators of the platform. They monitor and adjust the learning process. Teachers can also select students to manage the platform, who can collect students' problems and reflect these problems to the teachers so that teachers can solve the problems. Besides, teachers should guide students to use WeChat reasonably and appropriately. Apply Wechat in the English teaching gives students a reason to use cell phones and WeChat. Without supervision and guidance, students who lack self-control will be addicted to mobile games. Therefore, teachers should offer students guidance concerning their activity on the phone and give them adequate regulation and control so that learning purpose can be achieved.

2) Supporting role: WeChat Official Platform used as teaching aids can not replace Classroom teaching. Nowadays, teachers should still focus on classroom teaching [5]. In the process of using WeChat, teachers should solve the problems found in practical application and optimize WeChat Official Platform teaching methods to give full play to the supporting role of WeChat Official Platform.

\section{CONCLUSION}

In China, College English is a public basic subject. Study in the first classroom is not enough. As the rapid development of technology, the wide application of WeChat and its multiple functions bring a new teaching model. Applying WeChat Official Platform in college English teaching can supplement the first classroom and arouse students' interest in learning and establish a harmonious relationship between students and teachers, which ultimately lead to the improvement of students' English ability. In the future, based on the learners' feedback, explore the new media to assist teaching.

\section{REFERENCES}

[1] C. Yangjing, WeChat, how long will it is popular - based on the SWOT theory [J]. News Research, 2012 (2).

[2] H. Qiliang, On the WeChat's application in college English Reading Teaching [J]. Journal of Hubei University of Economics, 2016(2): 203.

[3] M. Xi, The application of WeChat official platform in adult education [J]. China Adult Education, 2018 (13).

[4] L. Fei, On the transformation of teacher's role under the condition of modern education technology [J]. The Silk Road, 2010(18): 124-125.

[5] L. Qian, Reform of college English teaching with WeChat [J]. Science \&Technology and Industry of China, 2014(2). 